\title{
DIETARY CALCIUM INTAKE IN GROUPS OF ACTIVE AND SEDENTARY ELDERLY IN THE CITY OF SANTOS, SAO PAULO, BRAZIL
}

\author{
C. de Carvalho Furtado, I. Lombardi
}

\begin{abstract}
Introduction: Currently, $10 \%$ of the Brazilian population is more than 60 years old. Calcium is an essential element to the body, it is produced endogenously and only acquired through daily intake of foods that contain it. The inadequate intake of this nutrient increases the risk of osteoporosis, as well as other diseases, such as hypertension and colon cancer. Therefore, the present study had the objective of evaluating the consumption of dietary calcium by active and sedentary elderly in the city of Santos/SPBrazil. Methods: Seventy elderly people of both genders were evaluated, on an average age of 69 and 75 years old for active and sedentary groups respectively. For nutritional assessment, we used 24-hour Dietary Recall and the quantification of calcium intake was done by software Avanutri 4.0. Weight, height and Body Mass Index (BMI) were measured for the assessment of body composition. Results: The data of calcium intake were compared with the recommendations advocated by DRI, which is of $1,200 \mathrm{mg} /$ day. Both groups consumed lower amounts of the recommended. However, the group of active elderly had a greater consumption (625,3 and 546,1mg for men and women respectively) in relation to the group of sedentary elderly (517,9 and 501,5mg for men and women, respectively), but there was no statistical difference between the groups. The low consumption may reflect on bone health and other bodily mechanisms of the evaluated groups. Therefore, nutritional education work is indispensable to inform the population.
\end{abstract}

Key words: Elderly, food intake, calcium.

\section{Introduction}

Due to the increase in longevity, the number of elderly people has tripled in the last 50 years. It is expected that this number is again triplicated in the next 50 years. It is estimated that, in 2050, one in every five people will be part of the elderly population and one in every five people will be part of the very elderly population (which means over 80 years old) (1).

According to the Brazilian Institute of Geography and Statistics (IBGE), there are currently in Brazil approximately 20 million people over or equal to 60 years old, which represents approximately $10 \%$ of the total population. In the city of Santos the amount of elderly people is higher than the country's average, there are more than $18 \%$ of the total number of individuals above 60 years old (2).

Eating is of great importance on people's lives, because it is from it that all daily activities take place, for example

Federal University of São Paulo, Santos, São Paulo Brazil.

Corresponding Author: Celine de Carvalho Furtado, Federal University of São Paulo, Santos, São Paulo Brazil, celine_carvalho@yahoo.com.br the ability to work, study, and others (3). The adequate intake of macronutrients and micronutrients are essential for a healthy aging. However, some factors can change the food consumption of the elderly, they are the physiological, social, cultural and health-related, not only the physiological age (4).

The need for adequacy of calcium intake has caught the attention in a number of studies (5). Calcium is an essential element to the body, it is produced endogenously and only acquired through daily intake of foods that contain it. Its importance in nutrition is related to the functions it performs in bone mineralization, especially in bone health, from the formation and maintenance of the structure to the rigidity of the skeleton (6). The recommended calcium intake for people above 60 years is $1,200 \mathrm{mg} / \mathrm{day}$, for both men and women (7).

Unfortunately, many elderly people consume calcium in an insufficient amount in terms of what is recommended $(8,9)$. According to data obtained from BRAZOS survey (Non-Profit Brazilian Osteoporosis Study) from 2007 about food consumption, $90 \%$ of the interviewees ingest $1 / 3(400 \mathrm{mg})$ of the amount of calcium recommended by DRI. Taking calcium 
supplement was mentioned by only $6 \%$ of the people (10). Many studies have demonstrated that the consumption of calcium prevents diseases such as osteoporosis, hypertension, obesity and colon cancer (5).

Nutrition can prevent or minimize the development of osteoporosis, and consequent fractures, by means of adequate intake of nutrients during the life cycle. It must have an adequate amount of calcium, vitamin D and vitamin $\mathrm{K}$ food sources associated with the smallest quantity of proteins, phosphates and sodium sources (11).

Having in mind the importance of adequate intake of this mineral for prevention/maintenance of bone health and other diseases, as well as a consequent better life quality for the elderly, this work has been done to estimate the consumption of calcium by a group of elderly residents in the city of Santos/SP.

\section{Patients and methods}

\section{Methods}

The present study was characterized as being of original nature, descriptive and explanatory of the transversal type, with a quantitative approach. The procedures were performed from field research and survey data. The project was approved by the ethics committee of the university under the following identification: UNIFESP $1287 / 11$.

\section{Population}

Seventy elderly people above 60 years old participated in the study. They are participants of the extension groups of UNIFESP / Campus Baixada Santista, and city residents of both genders, practitioners and nonpractitioners of physical activity.

\section{Criteria for Inclusion}

Volunteers of both genders, 60 years old or over, with no cognitive impairment, a Mini mental state examination above 18 points, which endangers the understanding of the guidelines on the procedures to be performed and physically capable of participating in the assessment.

\section{Criteria for Exclusion}

Inability to stay independent in orthostatism; Incapacitating neurological problems;

\section{Procedures}

The researcher explained the objectives and methods involved in the study to all volunteers. Those who agreed to participate signed the Free and Informed Consent Statement.

The tests and evaluations that were performed in the first part of the project were explained.

1. Mini Mental State Examination (Bertolucci, 1994).

2. Nutritional Assessment (Weight, Height, Body Mass Index and 24-hour Recall)

3. Level of physical activity IPAC - Short Version.

All procedures and evaluations were performed in a single step.

The quantification of calcium in food was performed by Avanutri software version 4.0 and the consumption data was compared to the recommendations advocated by Recommended Daily Intake (RDI, 2002) that is 1,200 $\mathrm{mg} /$ day, for the elderly of both genders.

\section{Statistical Analysis}

For data analysis, the software $\mathrm{R}$ version 7.0 was used. To compare the groups regarding the numerical variables of interest, Student's t test was employed for non-related samples. The results are presented in table I, at the end of this paper, and it allows us to affirm that Sedentary and Active people are different regarding the BMI variables and Stature. For studying the relationship between Calcium and the variables Gender and Group, the analysis of variance model with two fixed factors was used. We obtained a descriptive level of 0.225 , which allows us to say that there is no relationship between these variables.

\section{Results}

The sample studied was composed of 70 elderly people, who were classified according to their level of physical activity and thus classified as physically active and sedentary, in the first group 18 men and 19 women were evaluated, and in the second 9 men and 24 women.

The main descriptive characteristics are expressed in table 1. It was possible to observe in the assessment of Body Mass Index that both men and women of the group of active people are at the maximum limit of normality, on the other hand in the sedentary group the women present values that indicate overweight.

With regard to the consumption of Calcium both groups consumed an amount lower than the recommendations of DRI in 2010 which is $1,200 \mathrm{mg}$ per day. However, the group of active elderly had a higher consumption (625.3 and 546.1mg for men and women respectively) compared to the group of sedentary elderly (517.9 and 501.5mg for men and women respectively). Indicating a slightly higher consumption in the group of physically active elderly people, but without statistical significance. 
Table 1

descriptive Analysis of anthropometric variables in the two groups of elderly, Santos/SP, Brazil, 2013. (Values are expressed as mean and standard deviation)

\begin{tabular}{|c|c|c|c|c|}
\hline \multirow[b]{2}{*}{ Variables } & \multicolumn{2}{|c|}{ Active } & \multicolumn{2}{|c|}{ Sedentary } \\
\hline & Men $\mathrm{N}=18$ & Women $n=19$ & Men $N=9$ & Women $n=24$ \\
\hline Age (years) & $69 \pm 6$ & $69 \pm 6$ & $74 \pm 11$ & $77 \pm 9$ \\
\hline Weight (Kg) & $81.1 \pm 11.7$ & $66.1 \pm 8.9$ & $72.2 \pm 11.3$ & $65.4 \pm 9.6$ \\
\hline Height (m) & $1.72 \pm 0.05$ & $1.56 \pm 0.07$ & $1.67 \pm 0.04$ & $1.53 \pm 0.05$ \\
\hline BMI $\left(\mathrm{Kg} / \mathrm{m}^{2}\right)$ & $27.32 \pm 3.7$ & $27.02 \pm 2.9$ & $25.75 \pm 3.8$ & $27.97 \pm 4.0$ \\
\hline
\end{tabular}

Figure 1

Calcium Intake in Mg, Santos/SP, Brazil, 2013.

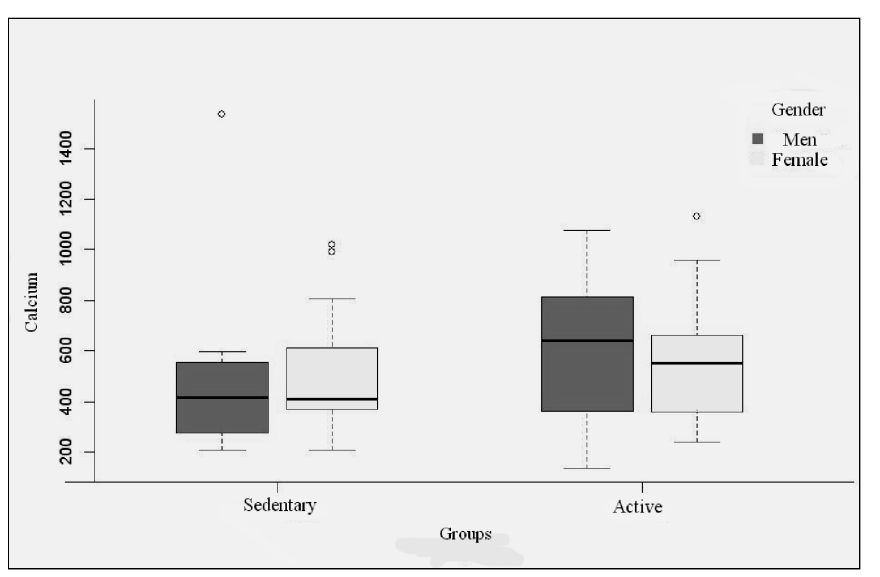

\section{Discussion}

In the present study, a low consumption of the mineral calcium was identified in both populations studied. This low consumption was due to the reduced intake of dairy foods that are considered as the main source of this nutrient. The results were obtained through the information provided by the questionnaire of 24 hours.

The collection of dietary data, with the use of 24-hour dietary recall or feeding records, when referring to one or few days, fails to capture the variations in day by day use. As a consequence, the distribution of intake is inflated, having a direct effect on interpretation and analysis of the results. An example of this is the under- or overestimation of the proportion of individuals below or above a given criterion of adequacy. The effect of the day by day variation, main source of variability of nutrients intake and energy, is reduced with the increased of days collected in each individual of the population of the study (12).

The indication of milk products ingestion for the Brazilian population, found in food guides, is of three servings a day. The recommendation of calcium intake for the elderly is reached by a daily consumption of five slices of mozzarella cheese or four glasses of milk. Foods that are sources of calcium and fat, such as whole milk and cheese, should be consumed with care (14). The main food source of calcium for most people is milk and its derivatives. In the United States, it represents $72 \%$ of the total calcium ingestion (15). The ingestion of four glasses (240 $\mathrm{mL}$ ) of milk is enough to achieve the recommendations for individuals above 50 years old. Yoghurt and cheese are also good sources of calcium. Foods with fat reduction are usually recommended, and it is important to note that there is little difference in the amount of calcium when compared to whole food; the skimmed products present a quantity a little higher (16). Dark green vegetables such as broccoli and kale are alternative sources of calcium, however the amount and bioavailability of calcium in these foods is lower when compared to milk and its derivatives (17).

In a study conducted with 152 elderly people, of both genders, above 60 years old, who reside in geriatric institutions in the city of Fortaleza- CE, 93\% had inadequate intake of this mineral, the value of calcium found was of $606.99 \mathrm{mg} /$ day (18). Another study, carried out in the city of Cascavel-PR, 53 elderly patients, around 66 years old, found an average consumption of $455.8 \mathrm{mg}$ (19). In a study conducted with 550 participants, $98 \%$ had an inadequate consumption (20).

When the adequacy of calcium intake was investigated in 140 elderly women, not institutionalized and literate, from the cities of Niterói, São Gonçalo and Nova Friburgo, Henriques found that only $6.7 \%$ of the sedentary elderly and $4.6 \%$ of the active ones showed calcium ingestion according to the American recommendation DRI. In addition, more than $50 \%$ of the population studied had an average consumption of this nutrient below two-thirds from what it is recommended (21).

A recent study conducted in Piauí, found an average consumption of $240.54 \mathrm{mg} /$ day for men and women above 60 years old who practice regular physical exercise (22).

On the other hand, a survey conducted with menopausal Chinese women who do not use supplementation has found an average consumption of $397 \mathrm{mg} /$ day, thus indicating this dietetic inadequacy an important risk factor for the development of bone fractures (23). 
According to Donangelo, the inadequate intake of calcium is the most obvious of nutritional factors for the development of osteoporosis (24). Nutritional studies indicate that an adequate calcium intake contributes to reduce the risk of developing this disease after menopause. The action of this mineral on the bone density should be checked in all different stages of life, with special attention to the periods of pregnancy and lactation. For the author, osteoporosis is an important endemic in Brazil, where an underestimated consumption of nutrients, including calcium, is often observed.

Analyzing the studies mentioned above, all the results were presented below the recommended, what support the findings of the present study, where no elderly reported to consume daily the amount of calcium recommended, having an average below $50 \%$ of the recommendation for both groups and genders.

\section{Final considerations}

The present study has demonstrated through dietary data extraction of a twenty-four-hour recall that the average consumption of calcium in the studied population is less than $50 \%$ of the nutritional recommendation, which may reflect on bone health and other body mechanisms. More studies of this type are needed to ensure that the statements are more concrete, however there is already a clear need to better inform people about the adequate intake of this nutrient in order to extend life quality and bone health over the years.

Nutritional Education and an interdisciplinary work involving changes of eating habits and also adoption of a new life style contribute to the maintenance of health and improve life quality during the aging process, and they should be stimulated and worked more and more.

Conflicts of Interest: None disclosed.

Ethics: None disclosed.

Funding: CAPES- REUNI.

\section{References}

1. Boones S. Bone romodeling, bone loss and bone fragility in old age. In: Roux C. ed. The living skeleton. Rueil-Malmaison: Wolters Kluwer Health; 2007.

2. Instituto Brasileiro de Geografia e Estatística. Síntese de Indicativos Sociais: Uma análise da população brasileira, 2007. Disponível em: URL $<$ HTTP/ / www.ibge.gov.br. $>$ Acesso em 10/10/12.
3. Galisa, M.S; Biscolla, E; Gaudenci, N.S. Nutrição Conceitos e Aplicações. São Paulo: M.Books do Brasil, 2008. pg 3, 169, 170, 172, 173.

4. Marques, A,P,O; et al. Envelhecimento, obesidade e consumo alimentar em idosos. Rev. Bras. Geriatria e Gerontologia. Rio de Janeiro, v. 10, n. 2, 2007. Disponível em: http:/ / www.unati.uerj.br/tse/scielo.php?script=sci_ arttext\&pid=S1809-98232007000200008\&lng=pt\&nrm=iso. Acesso em: 01/09/2012.

5. Heaney RP. Calcium Intake and Disease Prevention. Arq Bras Endocrinol Metab 2006; 50:685-93.

6. Bueno AL. Avaliação do consumo de cálcio dietético e vitamina $\mathrm{D}$ e sua relação com parâmetros bioquímicos em pacientes com baixa estatura [Dissertação de mestrado]. Porto Alegre: Universidade Federal do Rio Grande do Sul; 2007.

7. Cozzolino SMF. Biodisponibilidade de nutrientes. $2^{\mathrm{a}}$ Edição. São Paulo. Manole; 2007.

8. Alaimo, K., MA. McDowell, RR. Briefel, et. al. Dietary Intake of Vitamins, Minerals, and Fiber of Persons Ages 2 Months and Over in the United States: Third National Health and Nutrition Examination Survey. Phase 1, 19881991. Advance Data from Vital and Health Statistics; No. 258. Hyattsville, MD: National Center for Health Statistics, 1994.

9. U.S. Department of Agriculture, Agricultura Research Service. Data tables: Results from USDA's 1994-96 Continuing Survey of Food Intakes by Individuals and 1994-96 Diet and Health Knowledge Survey [Online]. ARS Food Surveys Research Group. Available (under "Releases"): (1998, April).

10. Pinheiro MM, Jacques NO, Genaro PS, Ciconelli RM, Ferraz MB, Martini LA. Nutrient intakes related to osteoporotic fractures in men and women - The Brazilian Osteoporosis Study (BRAZOS). Nutrition Journal [aceito para publicação], 2008.

11. Jorge RA, Rodrigues CSC. Papel dos nutrientes na prevenção e no tratamento da osteoporose. Rev Bras Nutr Clin. 2009;24(1):66-71.

12. Tarasuk V, Beaton G. Statistical estimation of dietary parameters: implications of patterns in within-subject variation - a case study of sampling strategies. Am J clin Nutr. 1992; 55;22-7.

13. Philippi, ST., Latterza, AR., Cruz, ATR., Ribeiro, LC. Pirâmide alimentar adaptada: guia para escolha do alimentos. Revista de Nutrição, Campinas, v.12, n.1, p.65-80,1999.

14. Vitolo, M. R. Nutrição: da gestação ao envelhecimento. Rio de Janeiro: Ed. Rubio, 2008.

15. Gerrior S, Bente L. Nutrient Content of the US Food Supply 1990-97. Washington DC: US Department of Agriculture, Center for Nutrition Policy and Promotion; 2001. Home Economics Research Report 54

16. Greer FR, Krebs NF, Committee on Nutrition. Optimizing Bone Health and Calcium Intakes of Infants, Children, and Adolescents. Pediatrics 2006; 117:578-85.

17. Weaver CM, Heaney RP: Food Sources, Supplements, and Bioavailability. In: Weaver CM, Heaney RP, editors. Calcium in Human Health, Totowa, Human Press Inc, 2006. p.129-42.

18. Menezes NT. Ingestão de cálcio e ferro alimentar por idosos residentes em instituições geriátricas de Fortaleza, CE. Ver Saúde Complem. 2005;1:110-9.

19. Ribeiro FB, Ruiz FS. Consumo de cálcio e fatores de risco para osteoporose em idosos participantes de um centro de convivência da terceira idade do município d Cascavel PR [Monografia]. Cascavél: Faculdade Assim Gurgaez; 2008.

20. Lopes ACS, Caiaffa WT, Sichieri R. Mingoti SA, Lima-Costa MF. Consumo de nutrientes em adultos e idosos um estudo de base populacional: Projeto Bambuí. Cad. Saúde Pública. 2005;21 (4): 1201-9.

21. Henriques P. Avaliação antropométrica e dietética de idosas sedentárias e ativas. Dissertação para obtenção do título de mestre em Nutrição humana. Instituto de Nutrição. UFRJ, 1999.

22. Leal JB, Vasconcelos VMS, Santos AFL, Xavier, NJVT, Alberto SMC \& Pereira LMR. Consumo de cálcio dietético por idosos praticantes de atividade física em uma academia de Teresina, Piauí. Rev Bras Nutr Clin 2012; 27 (3): 164-9.

23. Haines CJ, Chung TKH, Leung PC. Dietary Calcium intake in postmenopausal Chinese Women. Eur. J. Clin. Nutr. 48:591-94, 1994.

24. Donalgelo C. Calcium and Osteoporosis. An Venez Nutr 47 (suppl.1): 13-6, 1997. 